\title{
Effects of intrauterine infusion of oestradiol-17 $\beta$ and prostaglandin E-2 on luteal function in non-pregnant heifers
}

\author{
L. P. Reynolds, D. A. Robertson and S. P. Ford \\ Department of Animal Science, 11 Kildee Hall, Iowa State University, Ames, Iowa 50011, U.S.A.
}

\begin{abstract}
Summary. Non-pregnant heifers (4/group) received intrauterine infusions of vehicle, oestradiol-17 $(150 \mathrm{ng})$, PGE-2 $(250 \mu \mathrm{g})$, or oestradiol + PGE-2 every $6 \mathrm{~h}$ from $12: 00 \mathrm{~h}$ on Day 13 to $06: 00 \mathrm{~h}$ on the day of subsequent oestrus or $06: 00 \mathrm{~h}$ on Day 21 (day of oestrus $=$ Day 0 ). Ten of 12 heifers receiving vehicle, oestradiol or PGE-2 returned to oestrus by Day 21 , whereas none of the heifers receiving oestradiol + PGE-2 returned to oestrus by Day 21. Jugular venous progesterone concentrations of vehicle- and PGE2-treated heifers declined rapidly after Day 15 and were basal $(<1 \mathrm{ng} / \mathrm{ml})$ by Day 20 . For heifers receiving oestradiol infusions, systemic progesterone levels did not decline until after Day 18, but were again basal by Day 20. Heifers treated with oestradiol + PGE-2 maintained elevated systemic progesterone levels until Day 21 after oestrus. In addition, the corpora lutea of the heifers treated with oestradiol + PGE-2 were heavier $(P<0.01)$ and contained more $(P<0.05)$ progesterone than did corpora lutea of the heifers in the other 3 groups on Day $21(3.4 \mathrm{~g}$ and $19.52 \mu \mathrm{g} / \mathrm{g}$ and $1.2 \mathrm{~g}$ and $1.65 \mu \mathrm{g} / \mathrm{g}$, respectively). It is concluded that oestradiol-17 $\beta$ and PGE-2, both of which are produced by the bovine conceptus and secreted from the gravid uterus, may act synergistically to maintain luteal function during early pregnancy in the cow.
\end{abstract}

\section{Introduction}

The embryonic 'signal' that results in the maintenance of luteal function occurs on about Day 16 after mating in the cow (Northey \& French, 1980) and Day 12 after mating in the ewe (Moor \& Rowson, 1966) and sow (Ford, Christenson \& Ford, 1982a). However, the identity of the molecule(s) that comprises this embryonic signal remains unknown. The bovine conceptus is capable of synthesizing oestradiol-17 $\beta$ in vitro by Day 13 after mating (Shemesh, Milaguir, Ayalon \& Hansel, 1979; Chenault, 1980), while porcine conceptuses can produce oestrone and oestradiol$17 \beta$ by Day 12 (Perry, Heap, Burton \& Gadsby, 1976). In addition, oestrogens are elevated in uterine flushings and venous blood of cows (Ford, Chenault, Christenson, Echternkamp \& Ford, 1981) and sows (Ford et al., 1982a) at the time of maternal recognition of pregnancy for each species. Intrauterine infusion of near physiological concentrations of oestradiol-17 $\beta$ results in an extension of the functional lifespan of corpora lutea (CL) in the sow (Ford, Magness, Farley \& Van Orden, 1982b). Prostaglandin (PG) E-2 is produced by cultured bovine blastocysts as early as Day 13 after mating (Shemesh et al., 1979; Lewis, Thatcher, Bazer \& Curl, 1982), and by ovine blastocysts by Day 14 (Lacroix \& Kann, 1982). Uterine luminal and venous concentrations of PGE2 are elevated on Day 15 in pregnant ewes (Ellinwood, Nett \& Niswender, 1979). In addition, infusion of PGE-2 into the uterus of non-pregnant ewes prolongs the functional lifespan of the CL (Magness et al., 1981). 
The purpose of this experiment was to determine the effects of intrauterine infusion of oestradiol-17 3 , PGE-2, or both hormones on the function of CL in non-pregnant heifers.

\section{Materials and Methods}

\section{Experimental procedures}

Sixteen non-pregnant Angus or Hereford $\times$ Angus heifers exhibiting oestrous cycles of normal duration (18-23 days) and of similar age and weight (1 $\frac{1}{2}-2$ years; $320-360 \mathrm{~kg}$ ) were used. Heifers were checked for oestrus twice daily throughout the experiment $(07: 30$ and 16:30 h), using a vasectomized bull, and were trained to stanchions at least 1 month before surgery to adjust them to handling and confinement. Food and water were removed from heifers $24 \mathrm{~h}$ before surgery, which was performed on Day 9, 10 or 11 after oestrus (day of oestrus = Day 0). Induction and maintenance of general anaesthesia were as described by Ford, Chenault \& Echternkamp (1979). The uterus and ovaries were exposed through a midventral incision, and the size and location of ovarian structures were recorded. A catheter was inserted into the lumen of the uterine horn ipsilateral to the ovary bearing the $\mathrm{CL}$, through a small incision at the tip of the horn. The intrauterine catheter was similar to one previously used in this laboratory (Ford et al., 1982b). The catheter had a 15-cm Silastic (Dow Corning Corp., Midland, MI) tubing tip (o.d. = 1.65 mm) that was sealed at the end and perforated at $3-\mathrm{cm}$ intervals to ensure delivery of hormones to the entire uterine horn (simulating hormone delivery by an elongated blastocyst). The catheter was exteriorized through a small flank incision and maintained in a cloth pouch glued to the flank area.

After surgery, heifers were assigned randomly, in equal numbers, to receive intrauterine infusions of vehicle (Group 1) consisting of $2 \%(\mathrm{v} / \mathrm{v})$ ethanol in sterile $0.9 \%(\mathrm{w} / \mathrm{v}) \mathrm{NaCl}$ plus $1 \%(\mathrm{v} / \mathrm{v})$ Combiotic (Pfizer, Inc., New York, U.S.A.), $150 \mathrm{ng}$ oestradiol-17 (Sigma, St Louis, MO; Group 2), $250 \mu \mathrm{g}$ PGE-2 (free acid; Upjohn Co., Kalamazoo, MI; Group 3), or oestradiol-17 $\beta$ + PGE-2 (Group 4) every $6 \mathrm{~h}$ from $12: 00 \mathrm{~h}$ on Day 13 to $06: 00 \mathrm{~h}$ on the day of subsequent oestrus if it occurred before Day 21 or $06: 00 \mathrm{~h}$ on Day 21. Each intrauterine infusion consisted of $0.8 \mathrm{ml}$ vehicle or hormone solution ( $150 \mathrm{ng}$ oestradiol-17 $\beta$ and/or $250 \mu \mathrm{g}$ PGE-2 per $0.8 \mathrm{ml}$ ) followed by a $0.8-\mathrm{ml}$ vehicle flush (volume of catheter $=0.8 \mathrm{ml}$ ). A stock solution of PGE-2 in ethanol was stored at $-20^{\circ} \mathrm{C}$, and solutions for intrauterine infusion were prepared daily $(06: 00 \mathrm{~h})$ in a sterile vial. The daily dose of oestradiol- $17 \beta$ was derived by multiplying the maximal venous-arterial difference in oestradiol-17 $\beta$ (Ford et al., 1981) across a gravid uterine horn by the daily uterine arterial blood flow (Ford et al., 1979), for cows on Days 14-18 of pregnancy. The daily dose of PGE-2 was the minimum intrauterine dose which has been shown to have no effect on the lifespan of the CL in heifers (Dalla Porta \& Humblot, 1983).

For each heifer, a sample of jugular blood was obtained by venepuncture once daily $(07: 00-$ $08: 00 \mathrm{~h}$ ) from Day 13 to Day 21 after oestrus. Plasma was obtained and stored at $-20^{\circ} \mathrm{C}$ until assayed for progesterone. All heifers receiving PGE-2 treatment plus 1 animal from the remaining 2 treatment groups (vehicle and oestradiol-17ß) were killed on Day 21 (08:00-10:00 h), and the uterus and ovaries were obtained. To minimize expense, the remaining 6 heifers were ovariectomized by midventral laparotomy between $08: 00$ and 10:00 h on Day 21. Placement of intrauterine catheters was verified at death or laparotomy. The diameters of ovarian structures were measured at the surface of the ovary, and CL were dissected from the ovary and weighed.

\section{Progesterone radioimmunoassay}

Plasma. The radioimmunoassay was identical to that previously reported and validated for progesterone in cow plasma in this laboratory (Ferrell, Ford, Prior \& Christenson, 1983). Plasma $(200 \mu \mathrm{l})$ was extracted in triplicate using benzene: hexane $(1: 2, \mathrm{v} / \mathrm{v})$ with one of the replicates receiving 12 000-15000 d.p.m. $\left[1,2,6,7-{ }^{3} \mathrm{H}\right]$ progesterone (sp. act. $97 \cdot 0 \mathrm{Ci} / \mathrm{mmol}$; New England 
Nuclear Corp., Boston, MA) to serve as the individual recovery for that set of duplicates. Recovery of $\left[{ }^{3} \mathrm{H}\right]$ progesterone averaged $86.5 \pm 0.3 \%$ (s.e.m.) and all values were corrected for procedural losses. Plasma extracts were assayed for progesterone using a fully characterized antibody (GDN337; Gibori, Antczak \& Rothchild, 1977). Sensitivity of the assay was defined as the amount of progesterone standard that yielded $95 \%$ of the counts/min in the buffer control tubes and ranged from 50 to $80 \mathrm{pg}$. With this method, mean blank value for plasma from an ovariectomized cow was $0.21 \pm 0.02 \mathrm{ng} / \mathrm{ml}$ (s.e.m., $n=10$ ). The precision and accuracy of the procedure were evaluated by adding $0 \cdot 10(n=4), 0 \cdot 25(n=4), 1.00(n=4), 2 \cdot 50(n=4), 5.00(n=4)$, and $10.00(n=4) \mathrm{ng}$ progesterone to plasma from the same ovariectomized cow. These standard plasmas were assayed and the progesterone concentration of the plasma blank was subtracted. The resulting concentrations $( \pm$ s.e.m.) were $0 \cdot 15 \pm 0 \cdot 01,0 \cdot 30 \pm 0.01,1 \cdot 17 \pm 0.03,2 \cdot 55 \pm 0.09,4 \cdot 87 \pm 0 \cdot 17$, and $10.81 \pm 0.52 \mathrm{ng} / \mathrm{ml}$, respectively. Within-assay variability was determined from replicates $(n=10)$ of a plasma pool from luteal-phase cows. The resulting concentration ( \pm s.e.m.) was $13.97 \pm 0 \cdot 21$ $\mathrm{ng} / \mathrm{ml}$ and coefficient of variation (CV) was $4.9 \%$. All plasma samples were assayed in a single assay.

$C L$. Corpora lutea were homogenized in $5.0 \mathrm{ml} 0.9 \%(\mathrm{w} / \mathrm{v}) \mathrm{NaCl}$ using a Polytron (Brinkmann Instruments, Inc., Westbury, NY), and the resulting homogenate was diluted with saline to a final volume of $15.0 \mathrm{ml}$. Aliquants of these homogenates were diluted $1: 4$ and $1: 400(\mathrm{v} / \mathrm{v})$ with sterile bottled $\mathrm{H}_{2} \mathrm{O}$ (Eli Lilly and Co., Indianapolis, IN), and $50-\mu$ l samples of these diluted homogenates were extracted and assayed as described above. Mean recovery $\left( \pm\right.$ s.e.m.) of $\left[{ }^{3} \mathrm{H}\right]$ progesterone was $87.9 \pm 0.3 \%$ and all values were corrected for procedural losses. The mean blank value for an homogenate of a corpus albicans from a cow on Day 4 after oestrus was $0.79 \pm 0.04 \mathrm{ng} / \mathrm{ml}$ (s.e.m., $n=8)$. The precision and accuracy were evaluated by adding $1(n=6), 5(n=6), 10(n=6)$, and 20 $(n=6) \mathrm{ng}$ progesterone to samples of the same luteal homogenate. Homogenate plus standards were assayed, and the resulting progesterone concentrations (after subtraction of the homogenate blank) were $0.97 \pm 0.08,6.17 \pm 0 \cdot 10,12.27 \pm 0.21$, and $22.78 \pm 0.27 \mathrm{ng} / \mathrm{ml}$, respectively. Withinassay variability was determined from replicates $(n=8)$ of a luteal homogenate from a luteal-phase cow. The resulting concentration ( \pm s.e.m.) was $12.92 \pm 0.23 \mathrm{ng} / \mathrm{ml}(\mathrm{CV}=5.1 \%)$. All CL were assayed in a single assay. The concentration of progesterone in each sample was adjusted from $\mathrm{ng} /$ $\mathrm{ml}$ homogenate to $\mu \mathrm{g} / \mathrm{CL}$ and $\mu \mathrm{g} / \mathrm{g}$ luteal tissue.

\section{Statistical analysis}

Changes in jugular venous progesterone concentrations were analysed by split-plot analysis of variance for repeated measures (Kirk, 1968). Content and concentration of progesterone in CL, as well as diameters and weights of CL on Day 21 after oestrus, were analysed by factorial analysis of variance. Differences between means were evaluated using orthogonal contrasts (Kirk, 1968). Differences between treatment groups in the proportion of heifers exhibiting oestrus by Day 21 were analysed by a $\chi^{2}$ test, and the lengths of the pretreatment and treatment cycles were compared using a paired $t$ test (Steel $\&$ Torrie, 1960). All data are reported as the mean \pm s.e.m.

\section{Results}

All intrauterine catheters were still in place on Day 21 after oestrus. For those heifers from which uteri were obtained, no infection or inflammation of the endometrium was apparent by gross observation, and the treated and non-treated horns were similar in appearance.

\section{Oestrous activity}

For the heifers in Groups 1, 2 and 3, 3 of 4, 3 of 4 and 4 of 4 were observed in standing oestrus by Day 21 , respectively. For heifers exhibiting oestrus, there was no difference $(P>0 \cdot 10)$ between the 
lengths of the pretreatment and treatment cycles $(20 \cdot 3 \pm 0.4$ versus $19 \cdot 2 \pm 0.4$ days). The proportion of heifers in Group 4 that exhibited oestrus by Day $21(0$ of 4$)$ was less $(P<0.03)$ than for the other 3 treatment groups.

\section{Ovarian structures}

All heifers used in this study had a single CL at surgery on Days 9,10 or 11 after oestrus, which averaged $24.2 \pm 1.0 \mathrm{~mm}$ in diameter. Diameters and weights of CL of heifers in Group 4 were greater $(P<0.01)$ than for those of the other 3 groups at ovariectomy on Day 21 (Table 1). Three of 4,2 of 4 and 2 of 4 heifers in Groups 1, 2 and 3, respectively, had a corpus haemorrhagicum (12.1 \pm $0.4 \mathrm{~mm})$ present on Day 21. The remaining 5 heifers had a large $(15.2 \pm 1.0 \mathrm{~mm})$ preovulatory follicle. None of the heifers in Group 4 had a corpus haemorrhagicum and their largest follicle averaged $10.2 \pm 0.8 \mathrm{~mm}$.

Table 1. Characteristics of corpora lutea on Day 21 of heifers in Groups 1 (vehicle), 2 (oestradiol-17ß), 3 (PGE-2) and 4 (oestradiol-17 $\beta+$ PGE-2)*

\begin{tabular}{|c|c|c|c|c|c|}
\hline Group & $\begin{array}{l}\text { No. of } \\
\text { heifers }\end{array}$ & Diameter (mm) & Weight (g) & $\begin{array}{c}\text { Progesterone } \\
\text { content }(\mu \mathrm{g} / \mathrm{CL})\end{array}$ & $\begin{array}{c}\text { Progesterone } \\
\text { conc. }(\mu \mathrm{g} / \mathrm{g} \text { tissue })\end{array}$ \\
\hline 1 & 4 & $13 \cdot 0 \pm 1 \cdot 2^{\mathrm{a}}$ & $1 \cdot 1 \pm 0 \cdot 4^{\mathrm{a}}$ & $2 \cdot 22 \pm 2.06^{\mathrm{a}}$ & $1 \cdot 12 \pm 0.94^{a}$ \\
\hline 2 & 4 & $15.8 \pm 1.3^{\mathrm{a}}$ & $1 \cdot 6 \pm 0.3^{\mathrm{a}}$ & $4.61 \pm 2.06^{\mathrm{a}}$ & $2.92 \pm 1.60^{\mathrm{a}}$ \\
\hline 3 & 4 & $13 \cdot 0 \pm 1 \cdot 1^{\mathrm{a}}$ & $0.8 \pm 0.1^{\mathrm{a}}$ & $0.82 \pm 0.32^{\mathrm{a}}$ & $0.93 \pm 0.25^{\mathrm{a}}$ \\
\hline 4 & 4 & $21 \cdot 2 \pm 1 \cdot 3^{b}$ & $3.4 \pm 0.4^{b}$ & $64.60 \pm 33.58^{\mathrm{b}}$ & $19.52 \pm 10.83^{\mathrm{b}}$ \\
\hline
\end{tabular}

* Means ( \pm s.e.m.) within a column with different superscripts differ $(P<0.01$ for CL diameter, weight, and progesterone content; $P<0.05$ for CL progesterone concentration).

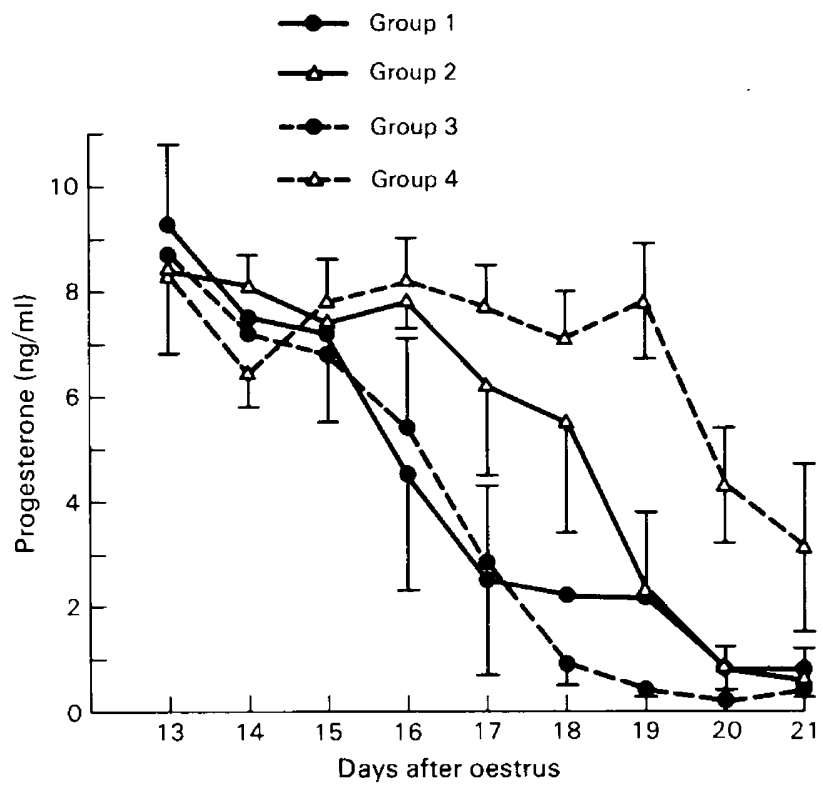

Text-fig. 1. Concentrations of progesterone in jugular venous blood of heifers receiving intrauterine infusions of vehicle (Group 1), oestradiol-17ß (Group 2), prostaglandin E-2 (Group 3 ), or oestradiol-17 + PGE-2 (Group 4) from Day 13 to Day 21 after oestrus ( $N=4$ per group). 


\section{Progesterone}

Luteal concentration and content of progesterone were greater for CL of heifers in Group 4 than for heifers in the other 3 groups (Table 1). The concentrations of progesterone $(\mathrm{ng} / \mathrm{ml})$ in jugular venous plasma were similar $(P>0 \cdot 10)$ for all treatment groups from Days 13-15 after oestrus (Text-fig. 1). From Days 16-18, plasma progesterone concentrations for Group 1 and Group 3 heifers declined to basal levels and were less $(P<0 \cdot 01)$ than for the heifers in Groups 2 and 4 which were similar. Jugular progesterone concentrations of Group 2 heifers decreased on Days 19 and 20 to levels similar to those observed for heifers in Groups 1 and 3 and were less $(P<0.01)$ than those in Group 4 heifers. Although systemic progesterone concentrations of Group 4 heifers had declined by Day 21 , they remained elevated $(P<0.05)$ when compared to the other 3 groups $(3.12 \pm 1.57$ versus $0.58 \pm 0 \cdot 12$; Text-fig. 1 ).

\section{Discussion}

Data from this experiment clearly demonstrate a synergism between oestradiol-17 $\beta$ and PGE- 2 in maintaining luteal function in heifers. Progesterone in systemic blood of the heifers treated with vehicle and PGE-2 began to decrease 3-4 days before oestrus, which is similar to previous reports for cyclic cows (Henricks, Dickey \& Hill, 1971; Ford et al., 1979). Intrauterine infusion of oestradiol-17 $\beta$ in the present study was able to extend luteal progesterone secretion for 3 days even though the occurrence of oestrus in oestradiol-treated heifers was similar to that of the vehicletreated heifers. When both oestradiol-17 $\beta$ and PGE-2 were infused, luteal weights and progesterone levels on Day 21 were similar to values reported previously for cows during the luteal phase of the oestrous cycle and pregnancy (Erb \& Stormshak, 1961). In addition, jugular venous progesterone concentrations in heifers treated with oestradiol-17 $\beta$ and PGE-2 were maintained for an additional 5-6 days compared to those in vehicle-treated heifers, averaging $3.12 \mathrm{ng} / \mathrm{ml}$ on Day 21 after oestrus. Northey \& French (1980) observed a similar maintenance of systemic progesterone levels when bovine embryos were flushed from the uterus on Days 17-19 after mating or when embryonic homogenates were infused into the uterus of non-pregnant cows from Days 14 to 18 after oestrus. Thus, intrauterine infusion of oestradiol-17 $\beta$ plus PGE-2, both of which are produced by the bovine conceptus and secreted from the gravid uterus, was able to extend luteal function in the absence of the conceptus.

The mechanism of action of oestradiol-17 $\beta$ and PGE-2 in maintaining luteal function remains unknown. Del Campo, Mapletoft, Rowe, Critser \& Ginther (1980) demonstrated that the luteotrophic effect of the bovine conceptus was exerted through a local vascular pathway. A local increase in blood flow to gravid uterine horns occurs coincident with maternal recognition of pregnancy in the sow, ewe and cow, and oestrogen administration has been shown to increase uterine blood flow in these species (see Ford, 1982, for review). Elevated uterine blood flow is associated with an increase in the amount of lymph draining the uterine horn (Fabian, 1981). The concentrations of steroid hormones in uterine lymph have been shown to reflect concentrations in the uterine lumen and uterine venous blood (Magness \& Ford, 1982; Ford et al., 1982a). Kotwica (1980) suggested that uterine lymphatics may be involved in the transport of prostaglandins from the uterine horn to the adjacent ovary. Therefore, oestrogens produced by the conceptuses may stimulate increased uterine blood flow, which could be important for the transport of substances such as prostaglandins from the lumen of the gravid uterus to the ovary.

Administration of oestrogen also stimulates increased ovarian blood flow in ewes (Rosenfeld, 1980). Infusion of oestrogen into an isolated uterine horn of non-pregnant sows preferentially stimulates progesterone secretion from the ipsilateral ovary (Ford et al., 1982b), and intrauterine infusion of oestradiol $-17 \beta$ in the present study extended systemic progesterone levels for 3 days. Oestrogens of embryonic origin may therefore enhance luteal function indirectly by causing increased blood flow to the ovary, with a subsequent increase in progesterone secretion. In support 
of this hypothesis, a transient increase in ovarian blood flow and progesterone secretion has been observed at the time of maternal recognition of pregnancy in sows (Magness, Christenson \& Ford, 1983) and cows (Ford et al., 1979; Ford \& Chenault, 1981). A direct effect of oestrogens on luteal function is unlikely because oestradiol-17 $\beta$ has been shown to inhibit LH-induced progesterone secretion by cultured bovine luteal cells (Williams \& Marsh, 1978).

Prostaglandin E-2 directly stimulates progesterone secretion and cyclic AMP production of bovine luteal cells in vitro, in a manner similar to that of luteinizing hormone (LH) (Speroff \& Ramwell, 1970; Marsh, 1971). In addition, PGE-2 has been shown to block PGF-2 $\alpha$-induced luteolysis when both prostaglandins were infused simultaneously into the ovarian artery (Henderson, Scaramuzzi \& Baird, 1977) or ovarian vascular pedicle (Reynolds et al., 1981) of nonpregnant ewes. This may be a direct luteotrophic effect on the CL because PGF- $2 \alpha$ inhibits LHinduced, but not PGE-2-induced, accumulation of cyclic AMP by cultured luteal cells (Khan et al., 1979). In addition, PGE- 2 was able to inhibit PGF- $2 \alpha$-induced loss of luteal LH receptors in nonpregnant ewes (Reynolds et al., 1981).

Although the present study indicates that both oestradiol-17 $\beta$ and PGE-2 are necessary for the maintenance of luteal function during early pregnancy in cows, the role of each hormone remains unknown. As suggested, oestradiol-17 $\beta$ may stimulate an increase in lymph and venous blood draining the gravid uterus and thus enhance the transport of substances such as PGE-2 from the uterine lumen to the ovary. Prostaglandin E-2 may then have a direct effect on the luteal cells to maintain progesterone secretion.

We thank Bill McDonald for the anaesthesia and technical guidance; Mahlon Shell for care of the experimental animals; Denise Braymen for typing the manuscript; and Dr J. R. Chenault, Upjohn Company, Kalamazoo, MI, for the heifers and PGE-2 used in this study.

This study partly fulfils requirements for the Ph.D. degree by L.P.R. Journal Paper No. J-11030 of the lowa Agriculture and Home Economics Experiment Station, Ames. Projects 1994, 2443, and 2444.

\section{References}

Chenault, J.R. (1980) Steroid metabolism by the early bovine conceptus. 1. $5 \beta$-reduction of neutral $\mathrm{C}_{19^{-}}$ steroids. J. Steroid Biochem. 13, 499-506.

Dalla Porta, M.A. \& Humblot, P. (1983) Effect of embryo removal and embryonic extracts or $\mathrm{PGE}_{2}$ infusions on luteal function in the bovine. Theriogenology 19, 122.

Del Campo, M.R., Mapletoft, R.J., Rowe, R.F., Critser, J.K. \& Ginther, O.J. (1980) Unilateral utero-ovarian relationship in pregnant cattle and role of uterine vein. Theriogenology 14, 185-193.

Ellinwood, W.E., Nett, T.M. \& Niswender, G.D. (1979) Maintenance of the corpus luteum of early pregnancy in the ewe. II. Prostaglandin secretion by the endometrium in vitro and in vivo. Biol. Reprod. 21 , 845-856.

Erb, R.E. \& Stormshak, F. (1961) Progestins in corpora lutea, ovaries, and adrenals after estrus and breeding of normal and abnormal cows. J. Dairy Sci. 44, 888896.

Fabian, G. (1981) The cyclical changes in the uterine lymphatics of the pig. Investigations on the perimetrium. Lymphology 14, 17-23.
Ferrell, C.L., Ford, S.P., Prior, R.L. \& Christenson, R.K. (1983) Blood flow, steroid secretion and nutrient uptake of the gravid bovine uterus and fetus. J. Anim. Sci. 56, 656-667.

Ford, S.P. (1982) Control of uterine and ovarian blood flow throughout the estrous cycle and pregnancy of the ewe, sow and cow. J. Anim. Sci. 55 (Suppl. II), 3242.

Ford, S.P. \& Chenault, J.R. (1981) Blood flow to the corpus luteum-bearing ovary and ipsilateral uterine horn of cows during the oestrous cycle and early pregnancy. J. Reprod. Fert. 62, 555-562.

Ford, S.P., Chenault, J.R. \& Echternkamp, S.E. (1979) Uterine blood flow of cows during the oestrous cycle and early pregnancy: effect of the conceptus on the uterine blood supply. J. Reprod. Fert. 56, 53-62.

Ford, S.P., Chenault, J.R., Christenson, R.K., Echternkamp, S.E. \& Ford, J.J. (1981) Effects of preimplantation bovine and porcine conceptuses on blood flow and steroid content of the uterus. In Cellular and Molecular Aspects of Implantation, pp. 436-438. Eds S. R. Glasser \& D. W. Bullock. Plenum Press, New York. 
Ford, S.P., Christenson, R.K. \& Ford, J.J. (1982a) Uterine blood flow and uterine arterial, venous and luminal concentrations of oestrogens on Days 11, 13 and 15 after oestrus in pregnant and non-pregnant sows. J. Reprod. Fert. 64, 185-190.

Ford, S.P., Magness, R.R., Farley, D.B. \& Van Orden, D.E. (1982b) Local and systemic effects of intrauterine estradiol-17 $\beta$ on luteal function of nonpregnant sows. J. Anim. Sci. 55, 657-664.

Gibori, G., Antczak, E. \& Rothchild, I. (1977) The role of estrogen in the regulation of luteal progesterone secretion in the rat after day 12 of pregnancy. Endocrinology 100, 1483-1495.

Henderson, K.M., Scaramuzzi, R.J. \& Baird, D.T. (1977) Simultaneous infusion of prostaglandin $\mathrm{E}_{2}$ antagonizes the luteolytic action of prostaglandin $\mathrm{F}_{2 \alpha}$ in vivo. J. Endocr. 72, 379-383.

Henricks, D.M., Dickey, J.F. \& Hill, J.R. (1971) Plasma estrogen and progesterone levels in cows prior to and during estrus. Endocrinology 89, 1350-1355.

Khan, M.I., Rosberg, S., Lahav, M., Lamprecht, S.A., Selstam, G., Herlitz, H. \& Ahrén, K. (1979) Studies on the mechanism of action of the inhibitory effect of prostaglandin $\mathrm{F}_{2 \alpha}$ on cyclic AMP accumulation in rat corpora lutea of various ages. Biol. Reprod. 21, 11751183.

Kirk, R.E. (1968) Experimental Design-Procedures for the Behavioral Sciences. Wadsworth Publishing Co., Belmont.

Kotwica, J. (1980) Mechanism of prostaglandin F-2 $\alpha$ penetration from the horn of the uterus to the ovaries in pigs. J. Reprod. Fert. 59, 237-241.

Lacroix, M.C. \& Kann, G. (1982) Comparative studies of prostaglandins $F_{2} \alpha$ and $E_{2}$ in late cyclic and early pregnant sheep: in vitro synthesis by endometrium and conceptus effects of in vivo indomethacin treatment on establishment of pregnancy. Prostaglandins 23, 507-526.

Lewis, G.S., Thatcher, W.W., Bazer, F.W. \& Curl, J.S. (1982) Metabolism of arachidonic acid in vitro by bovine blastocysts and endometrium. Biol. Reprod. 27, 431-439.

Magness, R.R. \& Ford, S.P. (1982) Steroid concentrations in uterine lymph and uterine arterial plasma of gilts during the estrous cycle and early pregnancy. Biol. Reprod. 27, 871-877.
Magness, R.R., Huie, J.M., Hoyer, G.L., Huecksteadt, T.P., Reynolds, L.P., Seperich, G.J., Whysong, G. \& Weems, C.W. (1981) Effect of chronic ipsilateral or contralateral intrauterine infusion of prostaglandin $\mathrm{E}_{2}\left(\mathrm{PGE}_{2}\right)$ on luteal function of unilaterally ovariectomized ewes. Prostaglandins Med. 6, 389 401.

Magness, R.R., Christenson, R.K. \& Ford, S.P. (1983) Ovarian blood flow throughout the estrous cycle and early pregnancy in sows. Biol. Reprod. 28, 1090-1096.

Marsh, J.M. (1971) The effect of prostaglandins on the adenyl cyclase of the bovine corpus luteum. Ann. N.Y. Acad. Sci. 180, 416-425.

Moor, R.M. \& Rowson, L.E.A. (1966) The corpus luteum of the sheep: effect of the removal of embryos on luteal function. J. Endocr. 34, 497-502.

Northey, D.L. \& French, L.R. (1980) Effect of embryo removal and intrauterine infusion of embryonic homogenates on the lifespan of the bovine corpus luteum. J. Anim. Sci. 50, 298-302.

Perry, J.S., Heap, R.B., Burton, R.D. \& Gadsby, J.E. (1976) Endocrinology of the blastocyst and its role in the establishment of pregnancy. J. Reprod. Fert., Suppl. 25, 85-104.

Reynolds, L.P., Stigler, J., Hoyer, G.L., Magness, R.R., Huie, J.M., Huecksteadt, T.P., Whysong, G.L., Behrman, H.R. \& Weems, C.W. (1981) Effect of $\mathrm{PGE}_{1}$ or $\mathrm{PGE}_{2}$ on $\mathrm{PGF}_{2} \alpha$-induced luteolysis in nonbred ewes. Prostaglandins 21, 957-972.

Rosenfeld, C.R. (1980) Responses of reproductive and nonreproductive tissues to $17 \beta$-estradiol during ovine puerperium. Am. J. Physiol. 239, E333-E339.

Shemesh, M., Milaguir, F., Ayalon, N. \& Hansel, W. (1979) Steroidogenesis and prostaglandin synthesis by cultured bovine blastocysts. J. Reprod. Fert. 56, 181-185.

Speroff, L. \& Ramwell, P.W. (1970) Prostaglandin stimulation of in vitro progesterone synthesis. J. clin. Endocr. Metab. 30, 345-350.

Steel, R.G.D. \& Torrie, J.H. (1960) Principles and Procedures of Statistics. McGraw-Hill, New York.

Williams, M.T. \& Marsh, J.M. (1978) Estradiol inhibition of luteinizing hormone-stimulated progesterone synthesis in isolated bovine luteal cells. Endocrinology 103, 1611-1618.

Received 4 May 1983 